\title{
How useful is the concept of transit migration in an intra-Schengen mobility context? Diving into the migrant smuggling and human trafficking nexus in search for answers
}

\author{
Roxane de Massol de Rebetz ${ }^{1}$ (D) \\ Accepted: 6 September 2020 / Published online: 11 October 2020 \\ (C) The Author(s) 2020
}

\begin{abstract}
When using the concept of transit migration, contemporary scholarly literature and policy documents typically refer to situations located outside or at the outskirts of the European Union. By analyzing the critical and empirical scholarship which uncovers the so-called gray area where it becomes hard to make clear distinctions that can be found at the nexus between migrant smuggling and human trafficking, the article aims to shed new light on the real-life vulnerabilities and dynamics that do not fit prototypical legal categories of either human trafficking or migrant smuggling. In so doing, the article discusses and analyzes legal and empirical scholarship that uncovers these vulnerabilities. The vulnerabilities observed are likely to be further enhanced in transit zones where stranded individuals within the EU aim to continue their (increasingly) fragmented/non-linear migration journeys. Therefore, the article proposes to consider the usefulness and the usage of the notion of "transit migration" in the context of Intra-Schengen border mobility and not just when discussing external border mobility. The article argues that the concept of transit migration, if carefully defined, and if particular vulnerabilities found in transit space are recognized, can serve as a helpful lens that can prevent falling into the trap of conceiving migrant smuggling and human trafficking as strictly separate phenomena.
\end{abstract}

Keywords Transit migration · Intra-Schengen $\cdot$ Human trafficking $\cdot$ Migrant smuggling

\section{Introduction}

Since the start of the Schengen Agreement in 1985, the right to free movement of people within the Schengen Area is a source of both challenges and opportunities within the European

Roxane de Massol de Rebetz

r.m.f.de.massol.de.rebetz@law.leidenuniv.nl

1 Van Vollenhoven Institute for Law, Governance and Society, Leiden Law School, Leiden University, Leiden, The Netherlands 
Union (EU). This is particularly true in a globalized world in which the increased movement of people across borders brings complex questions related to perception of erosion of sovereignty for nation states (see Dauvergne 2008). The so-called European asylum and migration "crisis" that drew global attention in 2015 triggered, among other things, reflections on external and internal border policing within and at the limits of the Schengen Area (Guild et al. 2015). According to the European Commission (2016), the absence of internal borders checks in the Schengen Area and its principle of free movement of people constitutes one of the most "cherished achievements" of the EU. However, in practice, both formal border controls (articles 24-26 Schengen Border Code) and informal border checks in border areas (article 23 Schengen Border Code) can be observed (van der Woude 2020). These increased (informal) border checks aim to prevent irregular migrants, including asylum seekers and refugees, from reaching their desired destination country, whether it is the UK or another EU country (see Paynter 2018).

As a result, it becomes apparent that specific zones within the Schengen Area are in fact becoming transit zones where irregular migrants are stranded for a variable period of time on their way to their desired destination country. This is, for example, the case in Calais (France), in the Maximilian Park (Belgium), or in Rome and Ventimiglia (Italy) (e.g., De Vries and Guild 2019; Tazzioli and Garelli 2018; Paynter 2018). Policy documents from the Belgian national rapporteur on human trafficking and migrant smuggling (Myria 2020), long lasting journalist investigations (e.g., Loore 2018) and NGOs (e.g., Caritas 2019) often document the lives of irregular migrants having to stay for weeks or months in the Belgian capital, waiting for their chance to reach the UK. One should imagine the life of Ali (alias), who comes from a West African country such as Eritrea, who together with 400-600 other individuals (see Loore 2018) in his situation leaves the Maximilian park of Brussels each night and its nearby train station to reach motorway areas. Once there, with or without the services of migrant smugglers, depending on the resources available to him, Ali will climb and hide in (sometimes refrigerated) trucks, hoping to reach the UK. If Ali is caught and stopped during his journey, he will then go back to the Maximilian Park trying his luck in the next days/weeks/months. While the national rapporteur (2020) acknowledges that someone can reside in a transit space in a legal manner, for example, when he lodged a demand for international protection, the focus of this article will be solely on individuals in irregular situation in the Schengen Area. As the NGO Caritas (2019) explained, individuals in irregular situations, such as migrants waiting in transit space in the Maximilian park, often face two choices to survive: to depend of networks of solidarity established and acting in the territory or to work in the black economy. The latter can lead to abuses and at times human trafficking when greedy employers take advantage of the vulnerable situation of people like Ali, especially if their financial resources dried up along the way (Caritas 2019). If Ali lacks financial resources to pay a migrant smuggler, he can resort to two other options as Loore (2018) thoroughly documented. He can either work for a smuggling organization himself as a first-line worker who spots and opens the trucks in exchange for a reduced fee or a free pass to the UK in the future (Hardt 2019, see later on the stereotypes around migrant's smugglers) or he can copycat the tactics of smugglers and attempt to reach the UK on his own (Loore 2018).

This scenario and the observations highlighted above bring to the foreground the concept of transit migration, which is currently scarcely used in the context of mobility within the European Union (e.g. De Vries and Guild 2019), let alone within the supposedly borderless Schengen Area (see van der Woude 2020 on the many borders that are in effect within the Schengen Area). Indeed, the literature on transit migration focuses predominantly on the 
peripheral zones of the EU (e.g. Düvell 2012; Collyer et al. 2014; Sørensen 2006). The concept sheds light on the stranded and vulnerable conditions of individuals on the move. Yet, it has been increasingly highlighted by recent studies that limiting legal migration channels and increasing border checks, also Intra-Schengen checks, leads to a fragmentation of the migration journeys for irregular migrants who are inside of the European Union. Consequently, the vulnerability of irregular migrants can potentially rise substantially in these inter-EU transit spaces. As illustrated in the scenario above, the vulnerable position can lead migrants to resort to professional networks of migrant smugglers, increase their debts, and incite them to accept (temporary) work in exploitative conditions to continue their paths, etc. (e.g., Mainwaring and Brigden 2016; Triandafyllidou 2018; O’Connell Davidson 2016).

The main goal of this article will be to question and then consider whether the contested concept of transit migration, taken in an Intra-Schengen context, could be helpful in shedding light on the blurred area found at the nexus of two other debated phenomena, namely, human trafficking and migrant smuggling. The adoption of the United Nation Convention against Transnational Crime (UNTOC) and its two additional protocols (hereafter Palermo Protocols) ${ }^{1}$ in 2000 produced a strict legal dichotomy between migrant smuggling and human trafficking (see Gallagher 2001; Hathaway 2008). The established legal categories trigger substantially distinctive protective regimes to either the "worthy" human trafficking (ideal) victim or the undeserving "culprit" smuggled individual (Dauvergne 2008; Kemp 2017; Baird 2016).

By exploring the scholarship that discusses the "gray area" located in-between prototypical cases of human trafficking and migrant smuggling, new light will be shed on the vulnerable positions of individuals "stranded" (for a definition of stranded, see "Approach and methodology" section) or stuck in motion in transit zones. These vulnerabilities to exploitation and abuse also result from the increased fragmentation of the migration journey which can be observed within the Schengen Area. The blurry lines that are generally observed by the scholarship between the two phenomena are likely to be further enhanced in transit spaces where individuals who aim to continue their migration journeys are stranded for undetermined periods of time within the EU. Hence, the concept of transit migration is argued here to serve as a helpful lens that can help us avoid falling into the trap of conceiving migrant smuggling and human trafficking as strictly separated phenomena.

After a brief explanation of the research methods and approach underlying this article (1), the concept of transit migration in an Intra-Schengen mobility context will be explained (2). Following a summary on the main differences between human trafficking and migrant smuggling, their points of intersection commonly identified by the scholarship will be highlighted (3). Subsequently, the representations and stereotypes generally attached to these phenomena will be deconstructed (4.1 and 4.2). As dealing with these two phenomena often intersects with issues of irregular migration, the potential instrumental use of the "fight against human trafficking and migrant smuggling" by nation states to advance their agenda in preventing irregular migration will be underscored (4.3). In the last section, the concepts and findings will be connected and the usefulness and potential limitations around the use of the concept of transit migration will be discussed.

\footnotetext{
${ }^{1}$ The aim of the article is not to repeat the main differences between the two crimes and the debates around the adoption of the UNTOC and its additional protocols as many authors already tackled the issue in a very insightful and thorough manner. The reader is invited to consult the articles of Gallagher (2008), Hathaway (2008) and Campana and Varese (2016) summarizing the distinct doctrinal opinions on the topic. See also the two relevant Palermo Protocols: UN the Protocol to Prevent, Suppress and Punish Trafficking in Persons, especially Women and Children and the UN Protocol against the Smuggling of Migrants by Land, Sea and Air
} 


\section{Approach and methodology}

The moderate social constructivist approach framed by Mertz (1994) serves as a background for this socio-legal article. Following this approach, it becomes apparent that laws are social constructions and do not reflect a neutral depiction of the reality (ibidem). Therefore, one should be careful to not have an "idealized" vision of the law as the latter is after all a "human artifact" (Calavita 2010: 3). Numerous scholars such as Giddens (1999), Bauman (2000), and Beck (1992) shed light on the tremendous changes in modern societies and the diverse and complex issues resulting from them. Nation states are therefore required to intervene to regulate these difficult matters. It is fair to write that migration-related issues such as migrant smuggling and to a certain extent human trafficking are complex to regulate in a globalized world (Franko 2017). In her description of the concept of discretion, van der Woude (2017) noted that a flexible approach is needed as a consequence to deal with "modern" complex societal issues and required not only rules but also discretion. While discretion is neither good nor bad in the sense that it can either lead to abuse or to positive results (see Weber 2003), it is nevertheless essential to acknowledge its existence. The presence of discretion can both be found at the implementation level and in the law-making process (Schneider 1992). Schneider (1992) explained that discretion was created by law and policy makers for diverse reasons; for example, where no consensus is reached by lawmakers who then pass on the responsibility to the decision makers, or when scenarios are too complex or messy to allow for clear rules (see also Weber 2003). The laws and regulations adopted to deal with both human trafficking and migrant smuggling and the distinction created between them can also be seen as a result of the fact that law cannot encompass an indefinite number of scenarios and is based on a construction of "false/constructed" "realities" or "truths". Hence, regarding the gray zone found at the nexus between migrant smuggling and human trafficking reflecting the messy reality of the field (see "Transit migration in the intra-Schengen mobility context" section), it is not only the implementation of the international and regional legal instruments that will be challenged. Indeed, the article will also focus on the manner the rules themselves are constructed in a way that leaves substantial room for interpretation to decision-makers and the interplay between the different actors responsible to deal with the phenomena.

The article builds on two distinct literature reviews, gathering the critical and empirical scholarship from a diverse range of disciplines such as law, sociology, critical criminology, and geography. The first one includes 58 peer-reviewed articles from the years 1980 to 2019 collected from 3 databases (Web of Science, Google Scholar, Criminal Justice Abstracts), as well as specialized journals in human trafficking/smuggling, (irregular) migration, and additional referral sampling. The selection was based on articles that assess transit migration, human trafficking, and migrant smuggling both critically and broadly. Particular attention was devoted to the theoretical description of the phenomena, policy practices, law-making, studies tackling stereotypes, and common representations attached to them, as well as the points of intersection between the phenomena. The selected articles were subsequently summarized and coded manually. The article is part of a broader research project "Dealing with human trafficking and migrant smuggling in Intra-Schengen border mobility context" which is partially financed by the National Dutch Police and aims to better understand the phenomena of human trafficking and migrant smuggling (see European Border Communities website ${ }^{2}$ ).

\footnotetext{
${ }^{2}$ https://europeanbordercommunities.eu/research/combatting-human-trafficking-and-human-smuggling-in-intraschengen-border-areas
} 
Within the research project's framework (see above), a systematic literature review was conducted between September 2017 and September 2018 and includes 181 articles and books, selected based on the following inclusion criteria: the literature needs to be 1) published after 1997 (Treaty of Amsterdam); 2) published in English; 3) contains research related to human trafficking and/or migrant smuggling, irregular migration, facilitation of entry/movement/ transit; 4) focuses on the EU, its member states and/or focuses on movement towards the European Union; 5) is empirically grounded except for material which proposes a model for analysis. The initial process of data collection, methods, and databases involved the same tools and techniques mentioned above. For the systematic literature review, material which met all the inclusion criteria was selected and coded using qualitative data analysis software (Atlas.ti). In total, 86 of the 181 articles and books which were coded had material relevant to answering the research question and included excerpts which appeared in the query reports. Regarding the analytical stage, a content analysis was done by creating code groups representing the concepts outlined at the end of the introduction. The coded quotes that came from the two literature reviews were extracted, organized based on the different themes mentioned supra, and analyzed with specific attention given to the political discourses on migrant smuggling, human trafficking, and the links between them as presented in the analyzed literature.

\section{Transit migration in the intra-Schengen mobility context}

\section{Transit migration: a difficult concept to define}

The concept of transit migration is not novel and has been used in distinct contexts throughout the years. Retracing the genealogy of the term, Collyer et al. (2014) observed that since the 1990 s, the term is almost exclusively used in policy documents as a way to describe irregular migratory movements (or desired movements) towards the EU and more specifically to refer to individuals stranded in so-called "buffer zones" at its external borders. There is no agreement on the definition of the broad terms "transit migration" or "transit migrant," which can explain why they have become connoted and politicized, particularly to discursively equate them with irregular migration, organized crime, and migrant smuggling (Düvell 2012). Transit migration can be seen as a blanket term devoid of legal meaning that can cover an array of migration categories and legal statuses: from mixed migration (encompassing inter alia refugees, asylum seekers, economic migrants) to (irregular) secondary movements (Sørensen 2006). In this article and building on the contributions of Schapendonk (2012: 579) and Carling (2002) to the transit migration debate, transit migration will be used to refer to "a phase of experienced immobility in process of movement in a specific migratory direction." Both scholars refer to the "migrant's aspirations of moving in a context of involuntary immobility" (Schapendonk 2012, 579). This definition has two advantages. On the one hand, the definition can be used in an intra-Schengen context as experiences of immobility can be experienced within the EU territory (see 2.2.). On the other hand, the definition allows to take into account the multiple change of plans during the migration path and breaks the assumption that there is always a fixed settlement at the end of the journey. It is equally important to define with precision what is meant by "stranded" in order to avoid further confusion. By stranded, the article builds on the definition of Schapendonk (2012) developed to describe migrants experiencing "a sense of immobility in the direction of the EU," in the sense that EU borders are "blocking their onwards movements" (580). This definition will also be used in the intra-Schengen context 
where border checks (e.g. van der Woude 2020) and governmental practices policing migrants (e.g. Tazzioli 2019; Edmond-Pettitt 2018) are experienced by migrants as obstacles to the continuation of their journey, either to other EU countries or to the UK.

Since 2014 and 2015, it is increasingly recognized that the label "transit migrant" has been used by the media in several member states to describe an individual present inside the socalled borderless Schengen Area. ${ }^{3}$ From a policy perspective, the term "transitmigrant/ transmigrant" made its appearance in 2015 in the Belgian policy, media, and governmental arenas to depict "a migrant or illegal migrant from Africa and Asia who wishes to go to the UK and stays on the Belgian or the French Northern coast in the meantime" (see Flemish dictionary 2016). The label "transit migrant," which does not refer to a legal category of individual, can and is likely to have an impact on the way authorities deal with migration issues, which includes challenging issues of human trafficking and migrant smuggling (de Massol de Rebetz 2018). Because "transit migrants" are merely seen as individuals who are not there to settle, it becomes easier to dehumanize them and increase the distance between "us" and "them" and/or passing the buck to other countries in terms of care and protection (see Claes 2018). Following Collyer et al.'s (2014) and Düvell's (2012, 2014) opinions, one must be cautious regarding the problematic politicization of the term transit migration. The term should not be used as a way to label individuals on the move as they can belong to distinct categories: refugees, asylum seekers, potential victims of human trafficking, etc. As it will be argued in the following sections, despite the risk of the politicization of the concept transit migration, the term as defined above is seen as useful to shed light on the vulnerable situations faced by stranded migrants both inside and outside of the Schengen Area. The living conditions and the particular vulnerabilities of individuals living in transit spaces can have an impact on the study of migrant smuggling, human trafficking, and their intersection.

\section{On the presence of transit zones within the Schengen area}

Papadopoulou (2004) described the transit migration phenomenon in Greece when she referred to individuals residing temporarily in a "waiting room" in the strategic "Schengenland" (168, 169). Perrin (2010) specifically wrote about the Schengen Area in his study aimed at identifying key characteristics of transit countries, such as their specific geographical location and the liberal immigration policies in place. Following the ethnographic research of Paynter (2018) on "transit migrants" (transiti migranti) in Rome, the transit migration concept is useful to refer to waiting zones in which individuals are located in limbo with the intention of continuing their migration journeys at a later stage. In their insightful contributions, Düvell $(2012,2014)$ and Sørensen (2006) explicitly link the restricted legal migration channels available to so-called transit migrants and the stranded conditions that they can experience en route. The increased securitization of the migration path to the EU also explains how migration journeys become longer and more perilous (see also Brunovskis and Surtees 2019; Brigden and Mainwaring 2016; Triandafyllidou 2018; Sanchez 2017; Hynes 2017; Carling et al. 2015). The "trajectory ethnography" conducted by Schapendonk (2018) on the im-/mobility of African migrants on their way to the EU and the distinct migration regimes imposed on them puts into question the "linearity" of migration journeys. Irregular migrants

\footnotetext{
${ }^{3}$ The term "transmigration", "migrante en transito" is often used in this particular context in national newspapers in some EU member states. See for example El Confidencial (Alonso 2019) and the Basque Radio Television EiTB (2018) for Spain; le Soir (2018) and de Standaard (2019) for Belgium
} 
might have to stay longer than expected in some places, sometimes detained and deported and/ or work in the shadow economy to finance the rest of their journeys (Kemp 2017).

As mentioned, Collyer et al. (2014) believed that the concept of transit migration was mostly relevant to describe the situation at the outskirts of the EU borders for several reasons. The authors stated that once a migrant reached the EU, his/her status as a "transit migrant" will not differ from any other irregular migrant present in the EU territory. According to them, once in the Schengen Area, the means of entry become legally irrelevant (see Dublin Regulation). This article argues the opposite and believes that the concept of transit migration, linked with or deriving from the increasingly restrictive border regime and the fragmentation of the migration journey, is crucial to describe both the situation at the external EU border and the situations in which migrants can find themselves while they are within the EU territory and in particular within the Schengen territory. The presumed absence of EU border checks within the Schengen Area (van der Woude 2020) makes the stranded situation of migrants even more odd.

Interestingly, despite the hesitation of the authors to use the concept in an IntraSchengen context, the reader can already observe contradictions as Collyer et al. (2014) acknowledge the historical tradition of several EU countries that served as transit spaces, as well as the challenging developments observed in Ventimiglia (Italy) since 2011 and more recently in the region of Calais bordering the UK. They described these spaces of transit as "bottlenecks," particularly in Southern European countries and in places bordering the Schengen Area such as Calais. Schapendonk (2012) also referred to the precarious living conditions of migrants who just made it to southern European countries such as Greece and Italy. The instability of their administrative status as well as their living conditions was detrimental in their desire to continue their migration journey or to go back to their country of origin. The recent studies of the geographer Tazzioli $(2019,2020)$ portray distinct zones inside the Schengen Area where migrants end up stranded. The stranded condition experienced by migrants challenges the idea of "the free internal mobility practices" that is not only the result of the recent reinstallation of national border controls (see also van der Woude 2020; Guild et al. 2015). More specifically, Tazzioli's $(2019,2020)$ ethnographic work conducted at the French/Italian and Italian/Swiss borders and in Calais (France) describes somewhat more conceived governmental strategies than the reinstallation of border checks. The strategies in place aimed at disrupting migrants' journeys and constantly diverting them from sensitive border zones. What she coined as "governing through mobility" can be seen as a deterrent and disruptive (administrative) strategy adopted to regain control over migrants' mobility that lengthens the migration journey. These border control methods contribute to the stranded condition of irregular migrants and force them to continuously be on the move throughout the territory to avoid the creation of new "jungles of Calais." Edmond-Pettitt (2018) further wrote about these operations of "dispersal" in her article on the policy of "hostile environment" in Calais (see also Collyer 2016). The empirical research of De Vries and Guild (2019) on "spaces of transit," which includes places inside the EU such as railway stations and semipermanent camps such as Calais, coined the term "politics of exhaustion" to describe a similar migration management strategy. This type of action is therefore enhancing the fragmentation of the migration journey. Focusing on the French/Spanish and French/ Italian border zones, Barbero (2018) and Barbero and Donadio (2019) further observed an internal outsourcing of border control responsibilities, particularly to peripheral states of the EU, supposedly considered to be the "guardians of the EU." 


\section{Blurry lines: reflection on the notions of consent/agency, exploitation, and debt}

\section{Law in the books: on the strict distinction between human trafficking and migrant smuggling}

The adoption of the UNTOC and the Palermo protocols ${ }^{4}$ produced a strict dichotomy between the two phenomena. The name of the UNTOC clearly indicates that human trafficking and migrant smuggling are dealt with through the spectrum of international cooperation and border control, as they are perceived as forms of organized crime resulting from globalization (Chacón 2010; Shelley 2010; Mitsilegas 2019). Within the EU and the Council of Europe, this organized crime approach was slightly mitigated for the sole case of human trafficking, at least in theory, by combining it with a more protective and human rights approach (RodríguezLópez 2018). Nevertheless, the demarcation line between the two crimes is maintained, which triggers a reflection on what Dauvergne (2008) described as the "all-important front in the battle for sovereignty and the nation state" (70). Globalization and the (unwanted) migration flows produced by the latter as well as the transformation of the nation states (see Sassen 2006) are important to understand the emergence of the Palermo Protocols (Dauvergne 2008). Dauvergne (2008) noted that as migration flows are perceived as a threat to state's sovereignty, the protocols were useful to determine individuals worthy of being admitted to the polity (see also Aas 2011 on borders and sovereignty). As controlling the mobility of individuals is one of the tool of expression of state sovereignty, the distinction between the two legal categories, which does not necessarily reflect the blurry reality, will help maintain the frontier between us and them (Dauvergne 2008; Haynes 2009; Skilbrei and Tveit 2008; Van Liempt 2011; Dandurand and Jahn 2020).This is particularly true when migration-related issues are being increasingly securitized (Mountz and Hiemstra 2014).

In a nutshell, the presumed major differences between migrant smuggling and human trafficking are the following: the presence/absence of consent, the purpose of exploitation, the length of the relationship between the trafficker/smugglers (temporality), ${ }^{5}$ the necessary presence of a cross-border dimension for migrant smuggling, and the distinct interests protected, namely the protection of the human rights of the trafficked victim and the protection of the State's interest in controlling its migration flows, respectively (Salt and Stein 1997; Gallagher 2008; Campana and Varese 2016; Hathaway 2008; see also the European Commission website "trafficking explained"). It must be highlighted that some of these differences such as the presence/absence of consent and the length of the relationship are not laid down in the international legal instruments. While the majority of academic, media and governmental outputs fit exclusively within one of these two categories, a growing fringe of the scholarship questions the operability of the definitions and the extent to which they reflect the reality (e.g., Baird 2016; Dandurand and Jahn 2020; Munro 2006). According to Baird (2016), the study of human trafficking and migrant smuggling has been uncritically and problematically aligned

\footnotetext{
${ }^{4}$ See the two relevant Palermo Protocols: UN the Protocol to Prevent, Suppress and Punish Trafficking in Persons, especially Women and Children and the UN Protocol against the Smuggling of Migrants by Land, Sea and Air

${ }^{5}$ It is assumed that the relationship between a migrant smuggler and his/her client ends at the arrival of the migrant in the country of destination or at the location previously agreed upon while the relationship between a trafficker and his/her victim is further continued in the country of destination with the exploitation dimension (see European Commission website: "Trafficking explained").
} 
with the strict legal categories established since 2000. The distinction overlooks the empirical evidence showing that both can be intertwined in a gray area and prevents a thorough understanding and comprehension of the phenomena and the dynamics in play between them. As Kemp (2017) explained, the blind reproduction of this fabricated distinction could reproduce the common discourses around the guilty accomplice migrants and deserving/ underserving victims of human trafficking. The main controversy concerns the notions of consent/agency, exploitation, and debt and the dynamics existing between these three elements. The following sub-section will shed light on the main areas of discussion that question this neat line of demarcation between the two crimes. Besides, explaining the concept of transit migration can be useful to bring more awareness to the vulnerabilities of individuals in transit spaces. This is important as the gray area identified between migrant smuggling and human trafficking is also likely to be found and bolstered in transit spaces.

\section{Law in action: when exploitation, consent, and debt complicate the dichotomy}

Many scholars share the opinion that while human trafficking and migrant smuggling can be easily differentiated in the books and that the definitions appear logical from a legal perspective, it is not always easy to make a distinction between the two phenomena in practice. They are perceived either as being intertwined or as forming a continuum (e.g. Dimitriadi 2016; Van Liempt 2011; Salt 2000; Derluyn and Broekaert 2005). Gallagher (2001) skeptically discussed the fact that the Palermo Protocols did not consider the operational links existing between both phenomena in practice. As many other authors, Gallagher (2008) illustrated her argument by the vast majority of cases in which migrants start their migratory journey voluntarily to end up in a situation of exploitation or abuse either en route or in the country of destination. This situation is caused by their vulnerable position, sometimes resulting from the heavy travel debt to be repaid (see also Carling et al. 2015; Munro 2006; Aronowitz 2009; Van Liempt 2011). According to Dauvergne (2008), ${ }^{6}$ Kemp (2017), and Dandurand and Jahn (2020), the "false dichotomy" between migrant smuggling and human trafficking boils down to the complex notions of consent. According to Van Liempt (2011), the dichotomy exists to facilitate the practitioner's discretionary task to decide who deserves protection and who does not. There is an assumption that an individual will either exercise full agency or have complete control over his migration path or will be forced/coerced to migrate to end up in a situation of exploitation. Yet, empirical findings show that the bulk of human trafficking and migrant smuggling cases hardly fits the prototypical categories and falls in an in-between gray area where traces of exploitation and abuse can be found and where the absence and presence of full or partial consent coexist (e.g., Kemp 2017; Munro 2006). Research has also illustrated that smuggled migrants can, at times, be in full control of their migration paths, whereas they, at other times, choose to relinquish their agency (temporarily) to the hand of the migrant smugglers; this is done in a strategic manner in their quest for a better future, which can involve high danger and possible exploitation to various degrees (Brigden and Mainwaring 2016; Sanchez 2017; Van Liempt 2011).

From a strict legal perspective, it is true that the Palermo Protocol (and the relevant European legal instruments on the matter ${ }^{7}$ ) consider that consent in human trafficking cases

\footnotetext{
${ }^{6}$ For concrete examples and cases falling in the "in-between" area, the reader is invited to consult the work of Dauvergne (2008, 80-90)

${ }^{7}$ See the EU Anti-Trafficking 2011/36/EU and Council of Europe Convention on Action against Trafficking in Human Beings (16 May 2005) also known as the Warsaw Convention
} 
involving adults should be deemed irrelevant when achieved through threat, coercion, fraud, deception, and abuse of power or abuse of vulnerability. The issue paper of the UN (2012a) regarding the abuse of vulnerability criteria described the latter as less tangible that the other means mentioned above. The document (UN 2012a) also pinpointed that the unclarity of the definition made room for ambiguities. Indeed, the abuse of a situation of vulnerability is described as "any situation in which the person involved has no real and acceptable alternative but to submit to the abuse involved" (UN 2012a: 3). This definition creates confusion for practitioners and allows nation states to have either a broad or as in many cases a narrow understanding of the term, which is unlikely to encompass topics such as poor socio-economic condition, family pressure, or the lack of opportunity in the country of origin (UN 2012a; see also Munro 2006). Despite further clarifications provided in a guidance note from the UN (2012b) on the existence and the abuse of a position of vulnerability, where it is urged to take the personal characteristics as well as the situational and circumstantial vulnerability of the individual into account to determine whether the latter had a real and acceptable alternative, it is up to the nation states to actually implement and clarify their legal frameworks and jurisprudence on the matter. As an illustration, France, despite a recommendation of the Group of Experts on Trafficking on Human Beings within the Council of Europe to do otherwise, provides an exhaustive list of situations of vulnerability which does not contain social, administrative, or economic vulnerabilities (see GRETA 2017).

Mai's (2016) study about Nigerian sex workers in France and the UK illustrates the ambiguity around the notion of consent. Contrasting with the common narrative on sexual exploitation, Mai (2016) found out that the majority of the sex workers interviewed chose to do sex work and justified it by their lack of legal status and their economic problems. The minority of sex workers who felt forced to perform sex work named the two same problems as factors underlying their conditions (see also Andrijasevic 2010). Kemp (2017), who researched both labor and sexual exploitation among African irregular migrants marginalized and excluded from the legal economy in Malta, confirmed this finding. The rationales behind their choice were the need to repay a previous traveling debt, sending remittance to their home countries or collecting more money to pay migrant smugglers to continue their journeys towards other EU countries. Quoting a UK police officer in the research performed by Munro (2006), "I've never found women chained up...but there are a whole series of other control factors, which mean that escape or running away isn't really an option" (328). Haynes (2009) further questioned the value of consent when the latter is likely to emanate from despair. This is particularly true when thorough discussions on power imbalance in a complex migration context were not tackled by lawmakers. It is safe to write that the migrants' consent as the means to distinguish human trafficking and migrant smuggling as highlighted in many policy documents (e.g. European Commission website "Trafficking Explained") is under serious criticism and can at times show the futility of the "free/forced neoliberal north-centric dichotomy" (Mai 2016: 6).

O'Connell Davidson (2013) reflected on the post-Enlightenment liberal tendency to perceive realities in a binary manner. Regarding issues around migration, this binary thinking results in building the clear demarcation lines highlighted above. The author (2013) strongly criticized this tendency and explained how debt-financed migration muddled with the assumption of neat dual realities. ${ }^{8}$ While contracting a debt with a migrant smuggler can result from an active and strategic choice to achieve a safer future, the voluntariness of it is questionable. This

\footnotetext{
${ }^{8}$ The reader is invited to consult the full article to have a deepest understanding of the argument of the author regarding the liberal understanding of freedom versus slavery and the role of debt in the latter
} 
is due, notably, to increasingly restrictive border policies and the social exclusion that migrants can face. The debt will also place the individuals in an unbalanced power dynamic, sometimes for years, but not necessarily for an indefinite period of time. This power dynamic will enhance their vulnerability and heighten the risk of exploitation, either in route/transit or in the country of destination (Joniken 2016; Skilbrei and Tveit 2008). O'Connell Davidson (2013) therefore suggested to replace the liberal "freedom versus slavery" dichotomy with "citizenship versus slavery," as she observed that non-citizen debtors did not have their rights and freedom protected by the State and were subject to an exclusion clause in society.

Already in 2011, before the migration "crisis" of 2015, a report from Europol (2011) identified "a point of contact" between human trafficking and irregular immigration due the fact that "transiting migrants were frequently exploited in illicit labor," which results from the fragmentation of the journey (22). Linking it back to the concept of transit migration and the situation of individuals stranded in transit spaces aiming to continue their journey onwards, the gray zone identified between migrant smuggling and human trafficking by scholars appears even grayer. Indeed, the blurred area found at the nexus between the two phenomena involves an interplay between facilitation, exploitation, extortion, debt bondage, as well as the simultaneous presence and absence of full and partial consent (see Carling et al. 2015; PeterkaBenton 2011). When individuals get stuck in so-called transit zones, their vulnerability to exploitation and abuse is likely to be enhanced (Brunovskis and Surtees 2019). Their quests for further mobility might presumably bolster the demand for the services of (more professionalized) migrant's smugglers, which can reinforce the debt and lead to potential (short-term) exploitation explained above (see Sanchez 2017; Trandafyllidou 2018; O'Connell Davidson 2017b; Andersson 2016). Moreover, as it will be further developed in the following section, numerous scholars (Lucht 2013; Zhang et al. 2018; Richter 2019) also examined the involvement of migrants in smuggling operations and the social embeddedness of the smuggling process. Brunovskis and Surtees (2019) further noted that this particular involvement can be considered as human trafficking as migrants can at times be coerced or have no choice but to take part in these unlawful activities. Despite the existence of non-punishment clause in both Palermo Protocols and in the relevant European legal instruments8, they are often really complex to use in practice (e.g. Villacampa and Torres 2017).

Dandurand and Jahn (2020) denounced the exclusive attribution of victimhood to human trafficking victims in the current mixed migration context. The authors (2019) pointed out the trouble in identifying signs of deception, exploitation, and abuse when distinct categories of migrants are on the move from country to country. It appears clear that the dichotomy is based on a simplified and at times erroneous representation of the reality experienced by migrants. If the sharp demarcation lines designed by lawmakers facilitate the task of practitioners in sorting the guilty smuggled individual from the innocent human trafficking victim, it makes it hard to provide a legal response to the multitude of scenarios situated in the blurry area involving different types of victims and degrees of agency and victimization.

\section{The impact of stereotypes on policymaking and implementation}

The distinction between human trafficking and migrant smuggling is also enshrined in strong gender and sexual stereotypes and ideologies. Women and children have higher chances of being identified as victims of human trafficking as long as they fit the prototypical profile of a pure and innocent victim devoid of agency, while men, who are generally perceived as 
economic migrants fully in control of their journey, will be commonly identified as smuggled individuals (Van Liempt 2011). In this section, the common stereotypes and typical representation regularly identified in the critical scholarship attached to both human trafficking (4.1) and migrant smuggling (4.2), as well as the potential issues resulting from their conflation (4.3) will be addressed. Kinney (2015) explained how stereotypical narratives on issues such as human trafficking could shape policies and affect their implementation on the ground. As Wilson and O'Brien (2016) noted, a policy never arises from an external reality and the way migrant smuggling and human trafficking are framed is also politicized, which can in turn shape the solutions introduced to deal with them, sometimes in an instrumental manner. As the phenomena and their potential intersection are often represented in an overly simplistic fashion, the consequences of victim identification and subsequent protection, as well as of the investigation and prosecution, are severe (e.g. Carling 2017; Chacón 2010). In the EU context, these framings can be damaging, as the legal frameworks in place to tackle both human trafficking and migrant smuggling share a border control approach, as they are intrinsically linked with "the fight against irregular migration" and transnational organized crime (see Spena 2016 for migrant smuggling and Rubio-Grundell 2015 for human trafficking). In each sub-section, the common representation attached to both human trafficking (4.1) and migrant smuggling (4.2.) will be identified. The aim is to shed light on the side effects and to a certain extent the instrumental use of common narratives (4.3) and assess their potential consequences for individuals stranded in transit spaces.

\section{The prototypical construction of human trafficking victims and villains}

The troublesome assumptions about consent and agency examined above (3) already revealed one of the core stereotypes about the prototypical human trafficking victim and created a distinction between the deserving and underserving victim who consented or who is complicit in their own exploitation (Rigby 2011). The empirical researches conducted by Ventrella (2017) in Italy, by Lavaud-Legendre (2017) in France, and by Constantinou (2013) in Cyprus clearly illustrate that the victimhood of an individual will become questionable once vague signs of consent appear, as well as in cases of sexual exploitation where a division between "good" and "bad" victims is made. There are numerous studies mentioning the problematic and predominant gendered and construction and representation of the pure, innocent, passive, worthy, "ideal" victim who is (physically) kidnapped to be sexually exploited (Brunovskis and Surtees 2008; Jacobsen and Skilbrei 2010; O’Brien 2016; Hoyle et al. 2011).

The frequent emphasis on physical and crude violence that victims of human trafficking are deemed to experience can lead to the disregard of (deceived) individuals in situations of exploitation who did not endure physical and/or sexual abuse (Maroukis 2017; O' Connell Davidson 2017b). Yet, the majority of cases do not necessarily involve physical violence, as forces leading to the exploitation of an individual are often complicated to identify (Frangež and Bučar Ručman 2017; Skilbrei and Tveit 2008). The study of Leser et al. (2017) with German practitioners illustrates how these common narratives on the "ideal victim" fail the test of the reality. According to the practitioners interviewed, many expressed their difficulties in finding "a proper victim" and alluded to the blurry lines around the notion of consent and the difficult differentiation between a forced worker and a migrant worker. The authors (2017) concluded that if victims did not show themselves as "worthy of compassion," they will likely be ignored or criminalized, as potential victims of human trafficking can quickly metamorphose into irregular migrants (see also van der Leun and van Schijndel 2016). 
In her study combining the most common stereotypes on human trafficking, RodríguezLópez (2018) confirmed the abovementioned issue and critically reflected on the over focus on sexual exploitation in comparison with labor exploitation. Despite the increased awareness towards labor exploitation, the lack of assistance for potential vulnerable male victims of labor exploitation was confirmed by the Group of Experts on Human Trafficking within the Council of Europe (GRETA 2018). Likewise, Heemskerk and Rijken (2011) observed that practitioners considered sexual exploitation as a more serious problem than labor exploitation. Similarly, the clear over focus on sexual exploitation in comparison to labor exploitation is also reflected in the scholarship (van Meeteren and Wiering 2019).

Rodríguez-López (2018) further identified the troublesome association of human trafficking with irregular migration and the treatment of human trafficking as a pure (transnational) organized crime problem with "ideal" deviant villains in charge, predominantly men of color (see also Chacón 2010; Kemp 2017). The consequences of oversimplifying the reality are the following: first, the threshold to attain the victimhood understood in a narrow manner will be presumably unreachable. This is particularly troublesome for individuals stuck in transit zones in blurry (temporary) exploitative/consensual scenarios who will be more likely to be recognized as guilty or complicit irregular smuggled individuals. Second, even if the EU adopted a more holistic approach, including human rights concerns towards human trafficking, the latter phenomenon is still treated as a transnational organized crime problem (Rubio Grundell 2015; Rodríguez-López 2018). As O’Brien (2016) and Chacón (2010) rightfully analyzed, this lens will feed and legitimize policies oriented to increase border control. The predominant focus in anti-human trafficking policies on a special kind of villain preying on passive and "blameless" victims is obscuring the responsibility of the nation states. Indeed, nation states are increasingly limiting legal migration channels and creating or reinforcing as a consequence the vulnerability of people on the move to smugglers and human traffickers. Generally speaking, the recurrent silence on structural factors is considered dubious, as it can heighten the risk of exploitation, especially at the nexus between migrant smuggling and human trafficking (Kemp 2017; Van Liempt 2011).

\section{The prototypical construction of the evil ruthless migrant smuggler part of an organized crime group}

It is certain that both human trafficking and migrant smuggling are hidden phenomena that are difficult to research. The scarcity of information also concerns secondary migration movements inside the Schengen area where the options to cross borders are more diverse (e.g., hidden trucks, public transportation, small boats in the North Sea). A report of the International Organization for Migration highlighted this specific knowledge gap vis-à-vis the scale of the smuggling phenomenon and its interconnection with human trafficking within the EU (McAuliffe and Laczko 2016). The phenomenon also suffers from stereotypical representations painting images of ruthless, profit-driven and hyper-hierarchical organized crime structures (e.g., Triandafyllidou 2018; Van Liempt and Sersli 2013).

While there are indicators that the smuggling journey can become increasingly expensive, dangerous, and violent at the outskirts of the European Union, this specific representation is strongly nuanced by the empirical scholarship (Van Liempt 2016; Sanchez 2017; Achilli 2015). Perkowski and Squire (2019) collected 250 narratives of smuggled individuals and explained how, from their perspective, there was no such thing as a homogenous prototypical "villain" smuggler. Migrants often considered smugglers as facilitators, helpers, saviors, or as 
the necessary alternatives, who are neither good nor pure evil (e.g., Achilli and Sanchez 2017; Mandic 2017). The sprawling organized crime narrative is also severely put into perspective as the majority of the scholarship paints a more diverse picture and agrees on the existence of loose and flexible smuggling networks constituted by interchangeable local/regional opportunists with precise and distinct tasks, but devoid of mafia-like bosses (Demir et al. 2017; Mitsilegas 2019; Staring 2004). As mentioned above (3), Richter (2019), Lucht (2013), and the insightful contributions found in the special issue edited by Zhang et al. (2018) deconstructed the image of the profit-driven migrant smuggler operating within a hierarchical and structured organized crime group by pinpointing the involvement of migrants themselves in smuggling operations. The latter can at times become more socially embedded and crossing borders can turn into a currency in certain transit spaces, where migrants see a business opportunity to help others in their migration journey onwards. Triandafyllidou (2018) wrote about complex systems existing on the basis of pre-existing local and regional community relationships, trust, information, interdependency, and profiteering. These findings do not deny the existence of brutality and violence during the smuggling process. Yet, as Sanchez (2017) observed, violence is unlikely to emerge out of a vacuum as vulnerability is tied to the absence of safe legal migration paths as well as social and financial capital.

The stereotypical representation of the migrant smuggling phenomenon and its intrinsic links with the "war/fight" against irregular migration is being strongly criticized by the scholarship. Spena (2016) stressed how the EU strategy to fight migrant smuggling was commanded by the ambition to fight irregular migration. When looking at the normative foundation criminalizing migrant smuggling, Mitsilegas (2019) questioned the way in which the securitization of the phenomenon is facilitated and legitimized by the use of recurrent discourses of evil smugglers at odds with the complex reality. The discursive and simplistic correlation between the dangerous criminal and the migrant smuggler figure, as well as the recurrent use of real yet extreme stories of smugglers abandoning migrants in the middle of the Libyan desert, pushing migrants with the help of automatic weapons inside overcrowded boats or leaving migrants suffocating hidden in trucks, obscure the decisive role of increasingly restrictive border policies in the migrant smuggling market (Andersson 2016; Van Liempt 2016; Lucht 2013).

Several scholars not only criticize the silence on structural factors, including socio-political and economic processes pushing migrants to start their migration journeys, but also shed light on the relationship between anti-smuggling policies used to crack down irregular migration and the migrant smuggling phenomenon (Perkowski and Squire 2019; Achilli and Sanchez 2017). Because issues around irregular migration often create feelings of unease, the construction of migrant smuggling as a security threat with identifiable culprits to be punished feeds the false belief that irregular migration can be halted (Van Liempt and Sersli 2013; Van Liempt 2016). Mainwaring and Brigden (2016) described how states were legitimizing and moralizing their harsher border control policies using the humanitarian and rescue narrative of the State as a savior of the migrant who takes irrational risks and is trapped in the hands of a cruel and ruthless smuggler. The authors (2016) also deconstructed the recurrent politicized discourse of the ceaseless linear flows of migrants starting from point A to arrive directly to point B, which can create an overwhelming feeling of invasion for the European population (see Bridgen and Mainwaring 2016).

The increased border enforcement and surveillance adopted to "fight" the evil smuggler and the fragmentation of the journey resulting from this "fight" has several consequences. First, the detailed overview of Sanchez (2017) combining empirical research on migrant smuggling demonstrates that ignoring the complexity of the migrant smuggling phenomenon has an impact on the latter in varied ways. Among other things, it can boost the sophistication and 
professionalization of migrant smuggling groups replacing community-based enterprises due to the increased criminalization of the phenomenon, it pushes individuals to go for more clandestine and hazardous routes, and it makes the smuggling fees increase the debt-exploitation risks. Mitsilegas (2019) and Triandafyllidou (2018) further observed the vicious circle created by this hardening-border approach, particularly vis-à-vis migrants in long and fragmented journeys, which increases their vulnerability. Carling (2017) recalled the importance of critically assessing the current strategy in place to tackle migrant smuggling, especially when evidence shows that smuggling services are indeed increasingly expensive but not automatically abusive or exploitative. If the author (2017) acknowledged that a migrant smuggler is not a "good Samaritan," he nevertheless warned against the use of simplistic portrayals of the latter to legitimize harsher immigration policies as a way to go "after the bad guys."

\section{The dangers of the instrumental conflation between human trafficking and migrant smuggling}

It was highlighted that the strict dichotomy between migrant smuggling and trafficking could be problematic, especially when based on the controversial notion of consent ("Transit migration in the intra-Schengen mobility context" section). Nevertheless, one should also be careful to not conflate the phenomena in an oversimplified manner. Making human trafficking and migrant smuggling synonymous with one another obscures the points of intersection and differences between these two phenomena, which can be detrimental for the conduct of relevant research (Peterka-Benton 2011). O'Connell Davidson 2016, 2017a, b) strongly criticized the fact that human trafficking is often framed by politicians, media, and NGOs as "modern day slavery." The author believes that choosing this framing makes it resonate with the transatlantic slave trade, which is not only deceitful from a historical perspective, but has practical consequences. First, as highlighted above (4.1), using this analogy stirs up the imagination of the public and street-level bureaucrats, who will then focus mainly on the physical suffering of victims and the "kidnapped/captured" narrative. Second, instead of focusing on the deeper and complex structural factors, the analogy shifts the lens towards the individual modern "slave holder." Finally, regarding the EU migration context, O' Connell Davidson (2017b) observed that politicians sometimes used migrant smuggling and human trafficking interchangeably. O' Connell Davidson (2017b) logically deduced the consequence of using the modern slave trade narrative on the policy-making arena. Considering that human trafficking is often perceived as a modern version of the Transatlantic Slave Trade, a similar appalling image will come to mind when thinking about human trafficking, which will help nation states legitimize stricter border controls. Nonetheless, it is important to signal that international legal instruments on migrant smuggling are not targeting irregular migration itself but the facilitation of the latter in order to obtain a direct or indirect financial or material benefit (see Palermo Protocol). Brunovskis and Surtees (2019) and Dandurand and Jahn (2020) described this problematic conflation as a way to curb and prevent migration flows. By mismatching migrants with modern slaves and migrant smugglers with human traffickers/ modern slave holders, Carling et al. (2015) discussed the issue as a "classic public relations move" from the EU authorities. Taking the example of the decision to intervene militarily close to the Libyan coast in targeting vessels of migrant smugglers, the document of the European Parliament on these interventions uses the following narrative: "the overarching objective is to help save lives by disrupting criminal networks of smugglers and traffickers" (European Parliament 2019, 1). Mandic (2017) and Carling et al. (2015) demonstrated that the 
conflation triggered much more political support, as it was oriented more towards dreadful traffickers than mere facilitators of irregular migration.

\section{On the usefulness and potential limitations of the transit migration concept}

The stereotypical representations of both phenomena are contributing to the creation of the "false realities/truths" underlying the dichotomy between migrant smuggling and human trafficking and their implementation on the ground. As mentioned in the methodology section, laws can hardly encompass in an unambiguous manner the multitude of scenarios found in reality. It is also questionable that the distinction between the phenomena is legally forced. Indeed, it is hard to see why a smuggled individual should cease to be smuggled once exploited or a trafficked victim cease to be smuggled. One can also wonder how the already contested concept of transit migration can be helpful to have a better understanding of the complex gray area found at the nexus between debated notions like migrant smuggling and human trafficking. This article does not aim at simplifying these concepts but to show their complexity, at the image of the messy reality empirically observed. The ambition is to stimulate scholars and practitioners to take into account the particularly vulnerable positions of individuals stranded in transit spaces, also in an intra-Schengen context where the absence of border checks and controls is assumed, and to question the strict categorization of individuals in one or another legal/administrative box. Indeed, if the blurry empirical reality of the gray zone highlighted above is overlooked, then it becomes easier to sort individuals into strict categories. This categorization can jeopardize the appropriate protection of migrants when looking deeper at the actual vulnerability, potential exploitation, and abuse that individuals are facing in transit zones (see Brunovskis and Surtees 2019). The consequences of this legal sorting can be extremely severe as one person, if identified as a human trafficking victim can enter the protective anti-trafficking framework while a smuggled individual will not. In the worst cases, the smuggled individual can be criminalized, even if a non-punishment clause exists in the UN Protocol against the smuggling of migrants. While the criminalization cannot take place for the mere fact of being smuggled, the criminalization can occur indirectly. This is, for example, the case if a migrant took part in smuggling operations and is not identified as a victim of human trafficking or if an individual in an irregular situation used a forged document (see FRA 2014 on the criminalization of migrants in the EU).

Calling for a better understanding of the complex situation of individuals in transit within the EU is crucial, as it is a prime example of the gray area at the nexus between migrant smuggling and human trafficking. For this reason, it is argued here that the use of the concept "transit migration," if precisely defined, can be considered useful and appropriate. Nonetheless, as Düvell (2012) advised, prudence is required when using the term "transit migration," as the latter can easily be politicized and equated with issues of irregular migration and organized crime. This conflation is problematic, as the issue is located in a mixed migration context, meaning that individuals in transit are not only "irregular" migrants but also refugees, asylum-seekers, and potential victims of human trafficking. Besides, the use of "transitmigrant/transmigrant" as a label can potentially dehumanize migrants and create further distance between "us and them" as the individuals are not there to settle. It would also offer governments the possibility of absolving themselves from any legal responsibility in terms of care and protection due to the temporary nature of the stay (Farcy and Desguin 2019; de 
Massol de Rebetz 2018). Hence, one should always be clear in the definition given to the term and the specific context in which it is being used.

\section{Conclusion}

The Commissioner for Human Rights within the Council of Europe, Mijatovic (2019), recently addressed how individuals on the move are vulnerable to exploitation and human trafficking. She called into attention that this group of individuals could be located at the external borders of the EU but were also living, often irregularly, inside member states of the EU and the Council of Europe or moving from one member state to another. Mijatovic (2019) admonished the previous warning of the Group of Experts on Action against Trafficking in Human Beings regarding the lack of assistance devoted to migrants arriving or already established in Europe, making them ideal targets for human traffickers (see also Brunovskis and Surtees 2019). Furthermore, the Commissioner (2019) pointed out the conflict of interest between antitrafficking and the recent anti-smuggling policies which, she underlined, are mostly aimed at preventing irregular migration. This recent call for the protection of vulnerable people on the move, both within Europe and at its periphery, accurately illustrates the interaction between transit migration, migrant smuggling, and human trafficking.

The goal of this article was to expose the gray areas created by the particular interplay of the concepts analyzed, their application in practice, as well as their problematic aspects. The latter was done by collecting, combining, and analyzing the critical scholarship on human trafficking and migrant smuggling and its nexus, as well as the recent empirical scholarship which brings to light intra-Schengen spaces of transit. Nevertheless, there is no intention to throw a stone at practitioners in charge of victim identification and protection, which is a complicated task for various reasons. ${ }^{9}$ As cases of human trafficking and migrant smuggling are often hidden and convoluted, the investigation and collection of evidence are highly difficult, especially with individuals on the move.

Following the urgent call of Baird (2016), it is certain that further empirically grounded and critical research on the nexus between human trafficking and migrant smuggling, also in the Intra-Schengen border mobility context, is of vital importance in order to have a better grasp of the situation on the ground. Empirical data about the "law in action" on these hidden phenomena must be brought to the front in order to improve the "law in the books." Contrary to the pre-conceived and simplified idea of human trafficking and migrant smuggling being recognized in a strictly separate manner, the literature unveiled the existence of "in-between" cases. These cases seldom fell into the prototypical legal categories, due to the presence of signs of (short-term) exploitation, abuse, and where the absence and presence of full or partial consent coexisted. Dauvergne (2008) adeptly described this legal predicament as "law specializes in drawing clear bright lines" (91). Based on the scarce but growing empirical findings highlighted in this article, one can assume that the aforementioned "in-between"/gray areas are likely to become more and more troublesome within Schengen.

\footnotetext{
${ }^{9}$ Many factors prevent concrete identification. Among other things: lack of trust towards the authorities, fear of retaliation from the traffickers, the need to pay a former debt or to pay remittance to one's family, the victims do not consider themselves as victim of human trafficking. For more information on the issues around victim's identification in a transit migratory context, the reader is invited to consult the recent work of Brunovskis and Surtees (2019)
} 
As individuals increasingly get stranded in transit spaces, their aspiration to continue their journeys, either from one member state to another in the EU or to the UK, can bolster the demand for migrant smuggling services. Such smugglers can increase their travel fees, which can raise the (initial) debt of the migrants and can also funnel individuals towards more hazardous and hidden roads due to restrictive border regimes. The debt/facilitation dynamic explained in "Transit migration in the intra-Schengen mobility context" section is likely to have an impact on subsequent (shortterm) exploitation en route or in the country of destination. Nonetheless, the stereotypes around the "ideal" victim of human trafficking create an unreachable threshold which will prevent the individuals situated in this gray area to be considered as such. The vicious circle brought to light above, which pushes individuals on the move into vulnerable positions, is not solely the result of unscrupulous deeds of ill-intended individuals. Section 4 of the present analysis deconstructed the solutions brought forth to tackle migrant smuggling and human trafficking, which are often based on prototypical representation of extreme cases.

In their fight against migrant smuggling and human trafficking, nation states often fail to mention structural factors pressing people to migrate and elude discussing their own responsibility in these processes. Yet, as Andersson (2016), Kemp (2017), and van Liempt (2011) observed, human trafficking and migrant smuggling can also constitute side-effects of EU restrictive migration policies. What clearly emerged from the empirical and critical scholarship is the conflict of interest existing between prioritized anti-trafficking, anti-smuggling, and anti-irregular migration policies. This conflict can have counterproductive consequences. In their battle for sovereignty, nation states decided to create a legal dichotomy which could, in theory, guide practitioners to sort the worthy and deserving (passive and innocent) victim from the guilty irregular migrant (Dauvergne 2008). While the international and European commitment to tackle human trafficking was generally applauded by scholars, the assumption that it was possible to fight it while preserving the full integrity of a nation's state border was questioned. As van der Leun and van Schijndel (2016) rightfully concluded, the relationship between the punitive approach adopted to fight against irregular migration and the protective approach adopted towards human trafficking should be re-examined rather than addressed as completely isolated battles. It becomes clear that rigid legal categories hardly fit the complex reality where the distinction between a "deliberate" and "incidental" exploited and/or abused victim can be considered nonsensical (Carling et al. 2015). This is the case in transit spaces where scholars brought to light the particular vulnerabilities of individuals on the move to exploitation, debt bondage, etc. The contradiction between these distinct yet linked policy agendas calls for the reminder that one cannot keep on feeding the monsters they are pretending to fight while keeping the "savior" face to legitimize debatable policies. As the proverb says: you cannot eat the cake and have it too.

Acknowledgments I would like to express my sincere appreciation to the anonymous reviewers for their thorough reading of this article and their insightful comments and suggestions. I'm particularly grateful for the assistance given by my supervisors Prof. dr. mr. Maartje van der Woude and Prof. dr. Masja van Meeteren.

Open Access This article is licensed under a Creative Commons Attribution 4.0 International License, which permits use, sharing, adaptation, distribution and reproduction in any medium or format, as long as you give appropriate credit to the original author(s) and the source, provide a link to the Creative Commons licence, and indicate if changes were made. The images or other third party material in this article are included in the article's Creative Commons licence, unless indicated otherwise in a credit line to the material. If material is not included in the article's Creative Commons licence and your intended use is not permitted by statutory regulation or exceeds the permitted use, you will need to obtain permission directly from the copyright holder. To view a copy of this licence, visit http://creativecommons.org/licenses/by/4.0/. 


\section{References}

Aas, K. F. (2011). 'Crimmigrant' bodies and bona fide travelers: surveillance, citizenship and global governance. Theoretical Criminology, 15(3), 331-346.

Achilli, L. (2015). The smuggler: Hero or felon?. Migration Policy Centre. Policy Briefs, 2015/10. Retrieved from Cadmus, European University Institute Research Repository, at: http://hdl.handle.net/1814/36296.

Achilli, L., \& Sanchez, G. (2017). What does it mean to disrupt the business models of people smugglers?. Policy briefs, 2017/09, migration policy centre. Retrieved from Cadmus, European University Institute research repository at: http://hdl.handle.net/1814/46165.

Alonso, J. (2019, February 28). Los 'búhos' que recogen migrantes en Irún y los mandan rumbo a Francia. El Confidencial. Retrieved from https://www.elconfidencial.com/espana/pais-vasco/2019-02-28/migrantestransito-irun-ayuda-grupo-voluntarios-noche-gautxori-martindozenea-cruz-roja_1843486/.

Andersson, R. (2016). Europe's failed 'fight' against irregular migration: ethnographic notes on counterproductive industry. Journal of Ethnic and Migration Studies, 42(7), 1055-1075.

Andrijasevic, R. (2010). Migration, agency and citizenship in sex trafficking. Basingstoke: Palgrave Macmillan.

Aronowitz, A. (2009). Human trafficking, human misery: the global trade in human beings. Westport: Praeger.

Baird, T. E. (2016). Defining human smuggling in migration research: An appraisal and critique. (EUI working papers; Vol. 2016, No. 30). Robert Schuman Centre for Advanced Studies.

Barbero, I. (2018). The European Union never got rid of its internal controls: a case study of detention and readmission in the French-Spanish border. European Journal of Migration and Law, 20(1), 1-27.

Barbero, I., \& Donadio, G. (2019). La externalización interna de las fronteras en el control migratorio en la UE. Revista CIDOB d'Afers Internacionals, 122, 137-162.

Bauman, Z. (2000). Liquid modernity. Cambridge: Polity Press.

Beck, U. (1992). From industrial society to the risk society: questions of survival, social structure and ecological enlightenment. Theory, Culture \& Society, 9(1), 97-123.

Brigden, N., \& Mainwaring, C. (2016). Matryoshka journeys: im/mobility during migration. Geopolitics, 21(2), 407-434.

Brunovskis, A., \& Surtees, R. (2008). Agency or illness - the conceptualization of trafficking: victims' choices and behaviors in the assistance system. Gender, Technology and Development, 12(1), 53-76.

Brunovskis, A., \& Surtees, R. (2019). Identifying trafficked migrants and refugees along the Balkan route. Exploring the boundaries of exploitation, vulnerability and risk. Crime, Law and Social Change, 72(1), 73-86.

Calavita, K. (2010). Invitation to law and society: an introduction to the study of real law. Chicago: University of Chicago Press.

Campana, P., \& Varese, F. (2016). Exploitation in human trafficking and smuggling. European Journal on Criminal Policy and Research, 22(1), 89-105.

Caritas. (2019). Sans-papiers en Belgique. Causes et consequences. Retrieved from https://www. caritasinternational.be/fr/asile-et-migration/sans-papiers-en-belgique-causes-et-consequences-long-read/.

Carling, J. R. (2002). Migration in the age of involuntary immobility: theoretical reflections and cape Verdean experiences. Journal of Ethnic and Migration Studies, 28(1), 5-42.

Carling, J. (2017, September 12). Batman in Vienna: Choosing How to Confront Migrant Smuggling [Web blog post]. Retrieved from https://blogs.prio.org/2017/09/batman-in-vienna-choosing-how-to-confront-migrantsmuggling/.

Carling, J., Gallagher, A. \& Horwood, C. (2015). Beyond definitions: Global migration and the smugglingtrafficking nexus, RMMS discussion paper, 2.

Chacón, J. M. (2010). Tensions and trade-offs: Protecting trafficking victims in the era of immigration enforcement. University of Pennsylvania Law Review, 158(6), 1609-1653.

Claes, T. (2018, March 1). Van mensen en (transit)migranten. [Web blog post]. Retrieved from .https://www.mo. be/wereldblog/van-mensen-en-transitmigranten.

Collyer, M., Düvell, F., de Haas, H., \& Molodikova, I. (2014). Introduction transit migration and European spaces. In F. Düvell, I. Molodikova, \& M. Collyer (Eds.), Transit migration in Europe (pp. 13-33). Amsterdam: Amsterdam University Press.

Constantinou, A. G. (2013). Human trafficking on trial: Dissecting the adjudication of sex trafficking cases in Cyprus. Feminist Legal Studies, 21(2), 163-183.

Dandurand, Y., \& Jahn, J. (2020). The failing international legal framework on migrant smuggling and human trafficking. In J. Winterdyk \& J. Jones (Eds.), The Palgrave international handbook of human trafficking (pp. 783-800). London: Palgrave Macmillan.

Dauvergne, C. (2008). Making people illegal: What globalization means for migration and law. Cambridge: Cambridge University Press.

De Standaard. (2019, September 13). Piek van transmigranten door Brexit. De Standaard. Retrieved from https:// www.standaard.be/cnt/dmf20190912_04605373 
de Vries, L. A., \& Guild, E. (2019). Seeking refuge in Europe: spaces of transit and the violence of migration management. Journal of Ethnic and Migration Studies, 45(12), 2156-2166.

Demir, O., Sever, M., \& Kahya, Y. (2017). The social organisation of migrant smugglers in Turkey: roles and functions. European Journal on Criminal Policy and Research, 23(3), 371-391.

Derluyn, I., \& Broekaert, E. (2005). On the way to a better future: Belgium as transit country for trafficking and smuggling of unaccompanied minors. International Migration, 43(4), 31-56.

Dimitriadi, A. (2016). The interrelationship between trafficking and irregular migration. In. E. Guild and S. Carrera (Eds.). Irregular migration, trafficking and smuggling of human beings: policy dilemmas in the EU (pp. 64-69). CEPS. Retrieved from https://www.ceps.eu/system/files/Irregular\%20Migration, \%20 Trafficking\%20and\%20SmugglingwithCovers.pdf.

Düvell, F. (2012). Transit migration: a blurred and politicised concept. Population, Space and Place, 18(4), 415-427.

Düvell, F. (2014). Transit migration in the European migration spaces politics. Determinants and dynamics. In F. Düvell, I. Molodikova, \& M. Collyer (Eds.), Transit migration in Europe (pp. 209-236). Amsterdam: Amsterdam University Press.

Edmond-Pettitt, A. (2018). Territorial policing and the 'hostile environment' in Calais: from policy to practice. Justice, Power and Resistance, 2(2), 314-334.

EITB. (2018, August 6). La situación de los migrantes en tránsito en Irun y San Sebastián 'está desbordada'. Euskal Irrati Telebista. Retrieved from .https://www.eitb.eus/es/noticias/sociedad/detalle/5774622 /migrantes-transito-san-sebastianirun-la-situacion-desbordada-denuncian/.

European Commission. (2016). Enhancing security in a world of mobility: Improved information exchange in the fight against terrorism and stronger external borders. COM(2016) 602 (Brussels).

European Parliament. (2019). Legislative Train. 8 Towards a New Policy on Migration. Retrieved from https:/www.europarl.europa.eu/legislative-train/api/stages/report/current/theme/towards-a-new-policy-onmigration/file/eunavfor-med-operation-sophia.

Europol. (2011). OCTA 2011. EU organized crime threat assessment. Retrieved from https://www.europol. europa.eu/activities-services/main-reports/octa-2011-eu-organised-crime-threat-assessment.

Farcy, J.-B., \& Desguin, N. (2019). Transmigrant: un vocable réducteur pour des réalités juridiques multiples. Revue du droit des étrangers, 196, 685-700.

FRA. (2014). Criminalisation of migrants in an irregular situation and of persons engaging with them. Retrieved from https://fra.europa.eu/sites/default/files/fra-2014-criminalisation-of-migrants_en.pdf.

Frangež, D., \& Bučar Ručman, A. (2017). Specific forms of human trafficking in Slovenia: overview and preventive measures. Police Practice and Research, 18(3), 230-244.

Franko, K. (2017). Criminology, punishment, and the state in a globalized society. In A. Liebling, S. Maruna, \& L. McAra (Eds.), The Oxford handbook of criminology (pp. 353-372). Oxford: Oxford University Press.

Gallagher, A. (2001). Human rights and the new UN protocols on trafficking and migrant smuggling: a preliminary analysis. Human Rights Quarterly, 23, 975-1004.

Gallagher, A. T. (2008). Human rights and human trafficking: Quagmire or firm ground-A response to James Hathaway. Virginia Journal of International Law, 49, 789-848.

Giddens, A. (1999). Risk and responsibility. Modern Law Review, 62, 1-10.

GRETA. (2017). Report concerning the implementation of the Council of Europe Convention on action against trafficking in human beings by France. Second evaluation round. Retrieved from https://rm.coe.int/greta2017-17-fgr-fra-en/16807454bf.

GRETA (2018). 8th General Report on GRETA's Activities. Retrieved from https://rm.coe.int/8th-/168094b073.

Guild, E., Brouwer, E., Groenendijk, K., \& Carrera, S. (2015). What is happening to the Schengen borders? CEPS Paper in liberty and security in Europe, 86, 1-23.

Hardt, M. (2019). « Le procès dit "de la solidarité" comme révélateur des faiblesses du cadre légal en matière de lutte contre l'aide à l'immigration irrégulière », Cahiers de l'EDEM. Retrieved from https://uclouvain. be/fr/instituts-recherche/juri/cedie/actualites/tribunal-de-premiere-instance-francophone-de-bruxelles-47echambre-correctionnelle-decision-du-12-decembre-2018.html.

Hathaway, J. C. (2008). The human rights quagmire of human trafficking. Virginia Journal of International Law, $49,1-59$.

Haynes, D. F. (2009). Exploitation nation: The thin and grey legal lines between trafficked persons and abused migrant laborers. Notre Dame Journal of Law, Ethics and Public Policy, 23, 1-72.

Heemskerk, M., \& Rijken, C. R. (2011). Combating trafficking in human beings in the Netherlands. In C. Rijken (Ed.), Combating trafficking in human beings for labour exploitation (pp. 73-158). Nijmegen: Wolf Legal Publishers.

Hoyle, C., Bosworth, M., \& Dempsey, M. (2011). Labelling the victims of sex trafficking: Exploring the borderland between rhetoric and reality. Social and Legal Studies, 20(3), 313-329.

Hynes, P. (2017). Trust and mistrust in the lives of forcibly displaced women and children. Families, Relationships and Societies, 6(2), 219-237. 
Jacobsen, C. M., \& Skilbrei, M. L. (2010). 'Reproachable victims'? Representations and self-representations of Russian women involved in transnational prostitution. Ethnos, 75(2), 190-212.

Jokinen, A. (2016). Irregular migration, trafficking in persons and prevention of exploitation. Irregular migration, trafficking and smuggling of human beings: Policy Dilemmas in the EU. Brussel Centre for European Policy Studies, 70-73.

Kemp, C. (2017). In search of solace and finding servitude: human trafficking and the human trafficking vulnerability of African asylum seekers in Malta. Global Crime, 18(2), 140-157.

Kinney, E. (2015). Victims, villains, and valiant rescuers: unpacking sociolegal constructions of human trafficking and crimmigration in popular culture. In M.-J. Guia (Ed.), The illegal business of human trafficking (pp. 87-108). Cham: Springer.

Lavaud-Legendre, B. (2017). De l'identification à la qualification de la traite: l'aveuglement des acteurs face à l'exploitation. Archives de Politique Criminelle, 39(1), 195-214.

Le Soir. (2018, September 15). Theo Francken veut ouvrir un centre fermé de crise pour les transmigrants. Le Soir. Retrieved from https:/www.lesoir.be/178596/article/2018-09-15/theo-francken-veut-ouvrir-un-centreferme-de-crise-pour-les-transmigrants.

Leser, J., Pates, R., \& Dölemeyer, A. (2017). The emotional leviathan-how street-level bureaucrats govern human trafficking victims. Digithum, 19, 19-36.

Loore, F. (2018). Migrants: l'autouroute du trafic. Paris Match. 28 October 2018.

Lucht, H. (2013). Pusher stories: Ghanaian connection men and the expansion of the EU's border regimes into Africa. In T. Gammeltoft-Hansen \& N. Nyberg Sørensen (Eds.), Migration industry and the commercialization of internal migration (pp. 173-189). New-York: Routledge.

Mai, N. (2016). 'Too much suffering': understanding the interplay between migration, bounded exploitation and trafficking through Nigerian sex workers' experiences. Sociological Research Online, 21(4), 1-14.

Mainwaring, $\dot{\mathrm{C}}$., \& Brigden, N. (2016). Beyond the border: Clandestine migration journeys. Geopolitics, 21(2), 243-262.

Mandic, D. (2017). Trafficking and Syrian refugee smuggling: evidence from the Balkan route. Social Inclusion, $5(2), 28-38$.

Maroukis, T. (2017). Keeping up appearances: the British public policy response to the trafficking of domestic workers in a changing regime of social protection. Journal of Immigrant and Refugee Studies, 15(2), 155-170.

de Massol de Rebetz, R. (2018). Transmigrant: one word to hide them all. Retrieved from https://www.law.ox.ac. uk/research-subject-groups/centre-criminology/centreborder-criminologies/blog/2018/12/transmigrant-one.

McAuliffe, M., \& Laczko, F. (2016). Migrant smuggling data and research: a global review of the emerging evidence base. Geneva: International Organization for Migration.

Mertz, E. (1994). Conclusion: a new social constructionism for sociolegal studies. Law \& Society Review, 28(5), $1243-1265$.

Mijatovic, D. (2019). Time to deliver on commitments to protect people on the move from human trafficking and exploitation. Retrieved from https://www.coe.int/en/web/commissioner/-/time-to-deliver-on-commitmentsto-protect-people-on-the-move-from-human-trafficking-and-exploitation.

Mitsilegas, V. (2019). The normative foundations of the criminalization of human smuggling: exploring the fault lines between European and international law. New Journal of European Criminal Law, 10(1), 68-85.

Mountz, A., \& Hiemstra, N. (2014). Chaos and crisis: dissecting the spatiotemporal logics of contemporary migrations and state practices. Annals of the Association of American Geographers, 104(2), 382-390.

Munro, V. (2006). Stopping Traffic? A comparative study of responses to the trafficking in women for prostitution. The British Journal of Criminology. 46 (2), 318-333.

Myria. (2020). Myriadoc 10 : La Belgique, une étape vers le Royaume-Uni. Retrieved from https://www.myria. be/fr/publications/myriadoc-10-migration-de-transit.

O' Connell Davidson, J. (2017a). The presence of the past: lessons of history for anti-trafficking work. AntiTrafficking Review, 9, 1-12.

O' Connell Davidson, J. (2017b). The right to locomotion? Trafficking, slavery and the state. In P. Kotiswaran (Ed.), Revisiting the law and governance of trafficking, forced labor and modern slavery (pp. 157-178). Cambridge: Cambridge University Press.

O'Brien, E. (2016). Human trafficking heroes and villains: representing the problem in anti-trafficking awareness campaigns. Social and Legal Studies, 25(2), 205-224.

O’Connell Davidson, J. (2013). Troubling freedom: migration, debt, and modern slavery. Migration Studies, 1(2), 176-195.

O'Connell Davidson, J. (2016). De-canting 'trafficking in human beings', re-centering the state. The International Spectator, 51(1), 58-73.

Papadopoulou, A. (2004). Smuggling into Europe: transit migrants in Greece. Journal of Refugee Studies, 17(2), $167-184$.

Paynter, E. (2018). The liminal lives of Europe's transit migrants. Contexts, 17(2), 40-45. 
Perkowski, N., \& Squire, V. (2019). The anti-policy of European anti-smuggling as a site of contestation in the Mediterranean migration 'crisis'. Journal of Ethnic and Migration Studies, 45(12), 2167-2184.

Perrin, B. (2010). Just passing through? International legal obligations and policies of transit countries in combating trafficking in persons. European Journal of Criminology, 7(1), 11-27.

Peterka-Benton, D. (2011). Human smuggling in Austria: a comparative analysis of data on smuggled migrants from former Yugoslavia and the Russian Federation. International Migration Review, 45(2), 215-242.

Richter, L. (2019). Doing bizness: migrant smuggling and everyday life in the Maghreb. Focaal, 85, 26-36.

Rigby, P. (2011). Separated and trafficked children: the challenges for child protection professionals. Child Abuse Review, 20(5), 324-340.

Rodríguez-López, S. (2018). (De) constructing stereotypes: media representations, social perceptions, and legal responses to human trafficking. Journal of Human Trafficking, 4(1), 61-72.

Rubio Grundell, L. (2015). EU anti-trafficking policies: from migration and crime control to prevention and protection. Policy briefs, 2015/09, migration policy Centre. Retrieved from Cadmus, European University Institute research repository at: https:/cadmus.eui.eu/handle/1814/35745.

Salt, J. (2000). Trafficking and human smuggling: a European perspective. International Migration, 38(3), 31-56.

Salt, J., \& Stein, J. (1997). Migration as a business: The case of trafficking. International Migration, 35(4), 467-494.

Sanchez, G. (2017). Critical perspectives on clandestine migration facilitation: an overview of migrant smuggling research. Journal on Migration and Human Security, 5(1), 9-27.

Sassen, S. (2006). Territory, authority, rights: from medieval to global assemblages. Princeton: Princeton University Press.

Schapendonk, J. (2012). Migrants' im/mobilities on their way to the EU: Lost in transit? Tijdschrift voor Economische en Sociale Geografie, 103(5), 577-583.

Schapendonk, J. (2018). Navigating the migration industry: migrants moving through an African-European web of facilitation/control. Journal of Ethnic and Migration Studies, 44(4), 663-679.

Schneider, C. E. (1992). Discretion and rules: a lawyer's view. In K. Hawkins (Ed.), The uses of discretion (pp. 47-88). Oxford: Clarendon Press.

Shelley, L. (2010). Human trafficking: a global perspective. Cambridge: Cambridge University Press.

Skilbrei, M. L., \& Tveit, M. (2008). Defining trafficking through empirical work: blurred boundaries and their consequences. Gender, Technology and Development, 12(1), 9-30.

Sørensen, N. N. (2006). Mediterranean transit migration and development: experience and policy options. In N. N. Sørensen (Ed.), Mediterranean transit migration (pp. 5-24). Copenhagen: Danish Institute for International Studies.

Spena, A. (2016). Human smuggling and irregular immigration in the EU: From complicity to exploitation? In E. Guild \& S. Carrera (Eds.), Irregular Migration, Trafficking and Smuggling of Human Beings: Policy Dilemmas in the EU (pp. 33-40). CEPS Retrieved from https:/www.ceps.eu/system/files/Irregular\%20 Migration,\%20Trafficking\%20and\%20SmugglingwithCovers.pdf.

Staring, R. (2004). Facilitating the arrival of illegal immigrants in the Netherlands: irregular chain migration versus smuggling chains. Journal of International Migration and Integration, 5(3), 273-294.

Tazzioli, M., \& Garelli, G. (2018). Containment beyond detention: The hotspot system and disrupted migration movements across Europe. Environment and Planning D: Society and Space, 0(0), 1-19.

Tazzioli, M. (2019). The politics of migrant dispersal. Dividing and policing migrant multiplicities. Migration Studies, 1-20.

Tazzioli, M. (2020). Governing migrant mobility through mobility: containment and dispersal at the internal frontiers of Europe. Environment and Planning C: Politics and Space, 38(1), 3-19.

Triandafyllidou, A. (2018). Migrant smuggling: novel insights and implications for migration control policies. The Annals of the American Academy of Political and Social Science, 676(1), 212-221.

United Nations. (2012a). Abuse of a position of vulnerability and other "means" within the definition of trafficking in persons. Issue paper. Retrieved from https://www.unodc.org/documents/humantrafficking/2012/UNODC_2012_Issue_Paper_-_Abuse_of_a_Position_of_Vulnerability.pdf.

United Nations. (2012b). Guidance $\bar{N}$ ote on 'abuse of a position of vulnerability' as a means of trafficking in persons in Article 3 of the Protocol to Prevent, Suppress and Punish Trafficking in Persons, Especially Women and Children, supplementing the United Nations Convention against Transnational Organized Crime. Retrieved from https:/www.unodc.org/documents/human-trafficking/2012/UNODC_2012_ Guidance_Note_-_Abuse_of_a_Position_of_Vulnerability_E.pdf.

van der Leun, J., \& van Schijndel, A. (2016). Emerging from the shadows or pushed into the dark? The relation between the combat against trafficking in human beings and migration control. International Journal of Law, Crime and Justice, 44, 26-42.

van der Woude, M. A. H. (2017). Chain reactions in criminal justice: discretion and the necessity of interdisciplinary research. The Hague: Eleven International Publishing. 
van der Woude, M.A.H. (2020). A patchwork of Intra-Schengen policing: Border games over national identity and national sovereignty. Theoretical Criminology, 24 (1), 110-131.

Van Liempt, I. (2011). Different geographies and experiences of 'assisted' types of migration: a gendered critique on the distinction between trafficking and smuggling. Gender, Place and Culture, 18(02), 179-193.

Van Liempt, I. (2016). A critical insight into Europe' s criminalisation of human smuggling: SIEPS Policy Paper. Retrieved from http://www.sieps.se/en/publications/2016/a-critical-insight-into-europes-criminalisation-ofhuman-smuggling-20163epa/.

Van Liempt, I., \& Sersli, S. (2013). State responses and migrant experiences with human smuggling: a reality check. Antipode, 45(4), 1029-1046.

Van Meeteren, M., \& Wiering, E. (2019). Labour trafficking in Chinese restaurants in the Netherlands and the role of Dutch immigration policies. a qualitative analysis of investigative case files. Crime, Law and Social Change, 72(1), 107-124.

Ventrella, M. (2017). Identifying victims of human trafficking at hotspots by focusing on people smuggled to Europe. Social Inclusion, 5(2), 69-80.

Villacampa, C., \& Torres, N. (2017). Human trafficking for criminal exploitation: the failure to identify victims. European Journal on Criminal Policy and Research, 23(3), 393-408.

Weber, L. (2003). Down that wrong road: discretion in decisions to detain asylum seekers arriving at UK ports. The Howard Journal of Criminal Justice, 42(3), 248-262.

Wilson, M., \& O'Brien, E. (2016). Constructing the ideal victim in the United States of America's annual trafficking in persons reports. Crime, Law and Social Change, 65(1-2), 29-45.

Zhang, S. X., Sanchez, G. E., \& Achilli, L. (2018). Crimes of solidarity in mobility: alternative views on migrant smuggling. The Annals of the American Academy of Political and Social Science, 676(1), 6-15.

Publisher's Note Springer Nature remains neutral with regard to jurisdictional claims in published maps and institutional affiliations. 